\title{
Violence against Women and Domestic Violence: General Framework and Overview of the Convention (Articles 1 and 2)
}

\author{
By Roberta Caragnano*
}

This paper analyses the International and European context which forms the base of the Convention on preventing and combating violence against women and domestic violence presented in 2011 and which entered into force on 1st of August, 2014. 2017 is the year of focused actions aimed at connecting all efforts across the European Union to stop violence against women; the 25 November will be the International Day for the Elimination of Violence against Women (with a unifying slogan, 'Say no! Stop violence against women') and with this is mind there are many activities organised by Member States, the EIGE, the European Parliament, civil societies and other institutions, under the umbrella of the campaign. The paper analyses the Convention that represents a milestone and the first legally binding instrument creating a comprehensive legal framework not only to protect women against all forms of violence, but also to prevent, prosecute and eliminate violence against women and domestic violence. Articles 1 and 2 describe the aims of the Convention dedicated to the purposes and scope of an international act. This act analyses the prevention of violence, in order to achieve full gender equality in order to eliminate discrimination against women, existing stereotypes and traditional practices regarding their health.

Keywords: Violence; Women; Gender Equality; Preventing; Convention

\section{Introduction}

Position of Problem

The Convention on preventing and combating violence against women and domestic violence (hereinafter "the Convention") was presented in 2011 and entered into force on 1st of August 2014.

This important act is aimed at preventing violence, protecting victims, and prosecuting the perpetrators and, in fact, recognises violence against women as a human rights ${ }^{1}$ violation - threatening women's health and their social and economic well-being - and it is significative because the phenomenon of violence

\footnotetext{
* Independent Researcher and lawyer; PhD (Labour Law and Industrial Relation) at University of Modena and Reggio Emilia, Italy; Co-Founding Member of Centre for Contemporary Labour Law - CCLL, Tbilisi, Georgia.

${ }^{1}$ McQuigg (2010). The article seeks to shed light on the question of how human rights law may be used in the area of domestic violence through the medium of a litigation strategy.
} 
against women is, unfortunately, very common in Europe and it is still a problem of society ${ }^{2}$.

Violence towards women and girls today is an extensive and serious violation of human rights, universally present in every country and area of the globe, in industrialised countries as in developing countries, albeit with variable characteristics and determined by specifics associated to the social and cultural environment of reference. Victims and their aggressors belong to all social, cultural and economic classes and abuse and violence is perpetrated in the majority of cases within the family ${ }^{3}$.

2017 is the year of focused actions aimed at connecting all efforts across the European Union to stop violence against women; the 25 November ${ }^{4}$ will be the International Day for the elimination of Violence against Women (with a unifying slogan, 'Say no! Stop violence against women') and with this aim many activities have been organised by Member States, the EIGE, the European Parliament, civil societies and other institutions, under the umbrella of the campaign.

Věra Jourová, the Commissioner, said,

"I want 2017 to be a game-changer in ending violence against women. By the end of the year, I hope that any woman experiencing violence will feel comfortable reporting it to the police and will get the support she deserves. And I want everyone in Europe to agree that sexual intercourse without consent cannot be justifiable under any circumstances".

According to a recent Eurobarometer report, Special Eurobarometer 452, Media pluralism and democracy, although $96 \%$ of Europeans realise that domestic violence is unacceptable, $27 \%$ still believe that non-consensual sexual relations can be justified in certain circumstances.

In the report we see the changes in opinion that have come about since the last survey in 2010 "Across the EU there has been a four percentage point decrease in the proportion who say domestic violence against women is common in their country, but much larger decreases in this view are observed amongst respondents in Slovakia (-16 pp), Latvia (-15 pp), Denmark and Finland (both $13 \mathrm{pp})$ ".

The map below (Figure no. 1) illustrates the situation in Europe.

\footnotetext{
2 The European Commission published in October 2015 a 'roadmap' on the (possible) EU accession to the Council of Europe Istanbul Convention, and, on the occasion of the International Day for the Elimination of Violence against Women named Roadmap A (possible) EU accession to the CoE Convention on preventing and combating violence against women and domestic violence, October 2015, 2015/JUST/010 and EU Commission, Factsheet Q\&A International Day for the Elimination of Violence against Women (24 November 2015) http://europa.eu/rapid/ press-release_MEMO-15-6150_en.htm accessed 20 June 2016.

3 Del Vecchio (2011) at p. 2; Degani (2000) at pp. 8-12.

${ }^{4}$ For Joint Statement on the International Day for the Elimination of Violence against Women, 25 November 2016 is possible to consult this link http://europa.eu/rapid/press-release_STATE MENT-16-3945_en.htm
} 
Figure 1. Map of Europe showing Violence against Women and the change in Opinion since the Last Survey in 2010

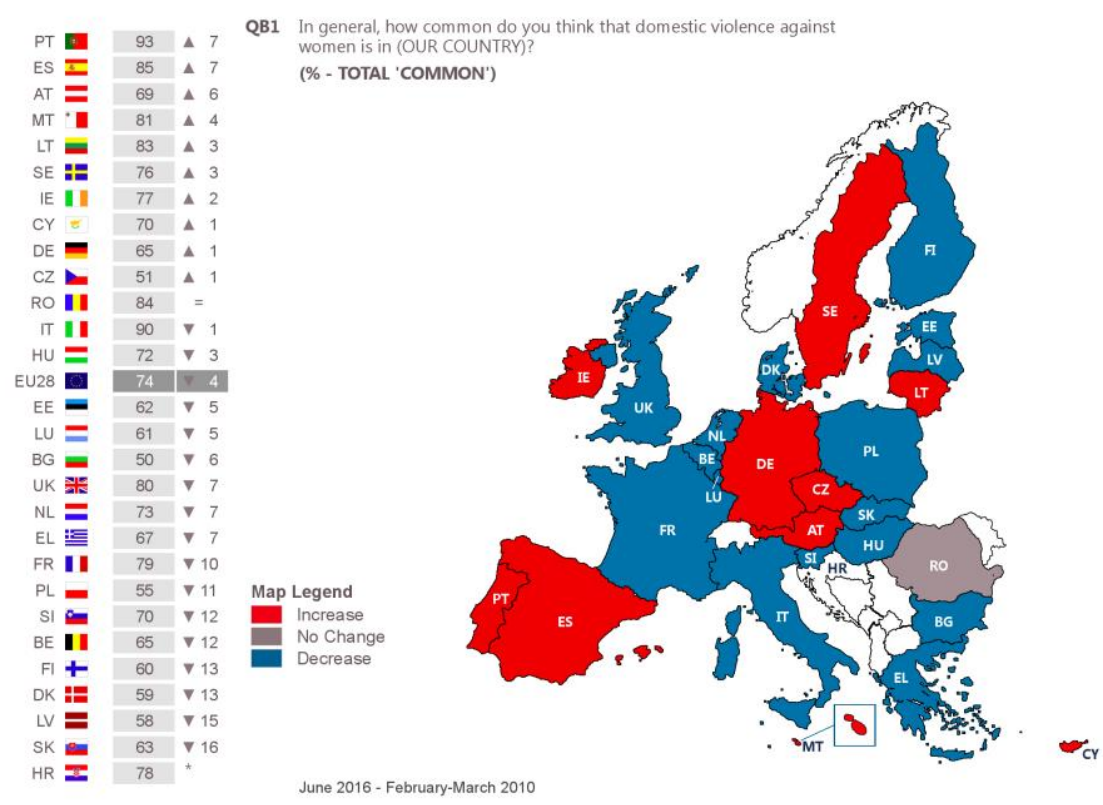

Base: All respondents ( $\mathrm{n}=27.818)$.

*Croatia was not covered in 2010.

Source: Special Eurobarometer 449: Gender-based violence 2016

Figure 2. Points of View and Perceptions of the Type of Violence against Women QB6 In your view, is violence against women more likely to occur... (MAX. 2 ANSWERS)

(\% - EU)

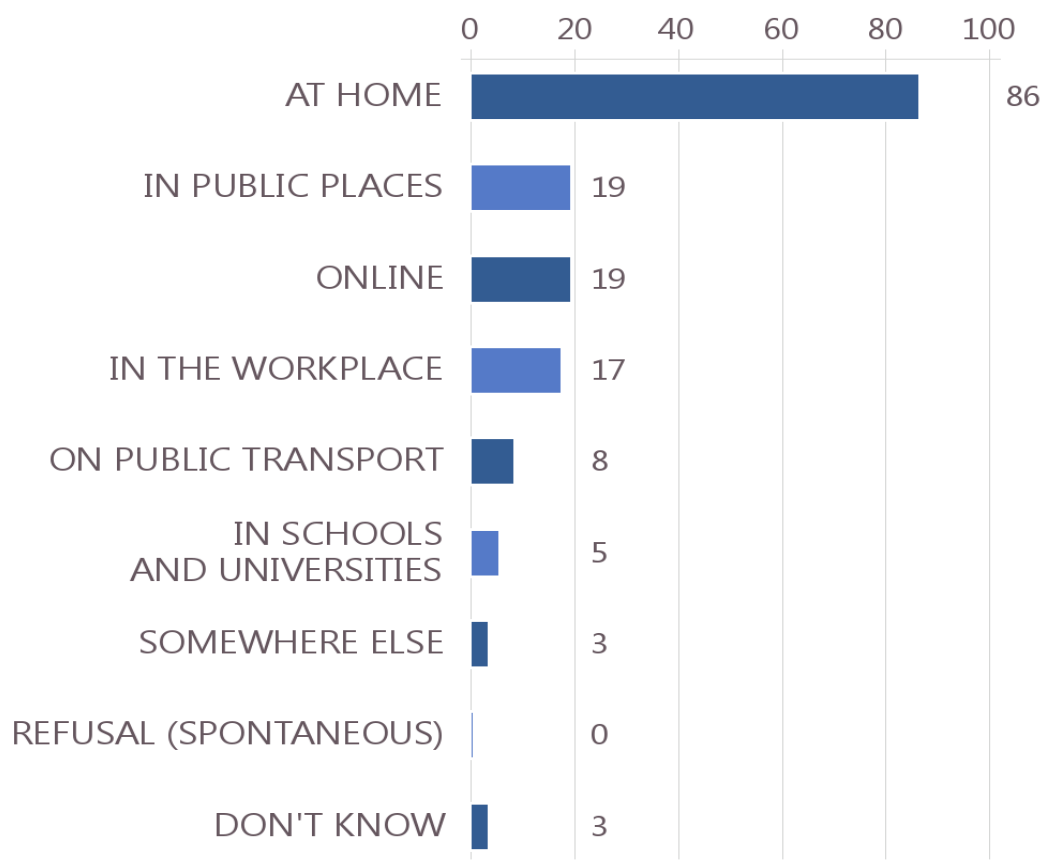

Base: Total respondents $(\mathrm{N}=27.818)$.

Source: Special Eurobarometer 449: Gender-based violence 2016 
The survey shows that a large majority of people think violence against women is more likely to occur at home and thus is the most mentioned option in each Member State. In figure no. 2 (above) different points of view and perceptions of the different types of violence against women (at home, in public places, on line, in the workplace, in public transport, in schools and universities, in other places) are illustrated.

In 2013 the EIGE (European Institute for Gender Equality) launched its gender equality index ${ }^{5}$, which measures gender equality between men and women ${ }^{6}$ in different fields.

The Index studies and compares gender gaps within a range of areas relevant to the EU policy framework (work, money, knowledge, time, power, health, violence and intersecting inequalities) including a 'satellite domain' on violence against women that "remains empty due to the lack of data".

Gender-based violence against women is both a cause and consequence of gender inequality and it also has important economic costs ${ }^{7}$ for the European Union estimated at $€ 226$ billion euro by the EIGE, in terms of lost economic outputs $^{8}$ from women missing work, health service costs, welfare costs and legal costs.

In the Report, Estimating the costs of gender-based violence in the European Union $^{9}$, EIGE analyses the costs of gender-based violence, compares different studies and literature and finally provides recommendations for member States and decision-making for a concrete and incisive process of policy development.

One of conclusions of the Report is

"whether the focus is on intimate partner violence against women or genderbased violence against men and women, over half of the cost is a result of the public estimation of the value placed on the physical and emotional impact that the violence causes. Around $13 \%$ of the cost is found in lost economic output. The cost of services makes up the remaining. Of these services, most resources are spent on criminal justice, followed by health services and social welfare. Less than 3\% is spent on specialised services to victims/survivors in order to help mitigate the damage of the violence and to prevent its recurrence. The proportion of the expenditure that is linked to prevention is currently small" ${ }^{\prime 10}$.

\footnotetext{
${ }^{5}$ EIGE (2013).

${ }^{6}$ For Glenn, Melis \& Withers (2009) at p. 42

${ }^{7}$ On indirect costs and in particular on cost of "non- intervention" see Walby \& Olive (2013). They extrapolated the 2001 costs of violence against women in England and Wales to the EU28 , adjusting for inflation to estimate that, for the reference year of 2011, the cost of inaction across the EU-28 was EUR 228 million» (Report EIGE 2014). In general on costs of inaction read also Patel \& Taylor (2011). For a study of economic costs in States extra UE see Laing \& Bobic (2002); Zhang, Hoddenbagh, McDonald \& Scrim (2012).

${ }^{8}$ For costs of lost economic output see Walby (2004); Day, McKenna \& Bowlus (2005); Skaperdas, Soares, Willman \&, Miller (2009); Waters, Hyder, Rajkotia, Basu, Rehwinkel \& Butchart (2004); Chan \& Cho (2010); Duvvury, Callan, Carney \& Raghavendra (2013).

${ }^{9}$ EIGE (2014).

${ }^{10}$ EIGE (2014) at p. 145.
} 
Table 1. Cost of Gender-based and intimate Partner Violence against Men and Women in EU Member States, by Extrapolation from UK case to Member States

\begin{tabular}{|c|c|c|c|c|c|c|}
\hline MS & Member State & Population' & $\begin{array}{l}\text { Cost of IPVAW } \\
\text { EUR }\end{array}$ & $\begin{array}{l}\text { Cost of IPV } \\
\text { EUR }\end{array}$ & $\begin{array}{l}\text { Cost of GBVAW } \\
\text { EUR }\end{array}$ & $\begin{array}{l}\text { Cost of GBV } \\
\text { EUR }\end{array}$ \\
\hline AT & Austria & 8408121 & 1818416256 & 2035912304 & 3763246487 & 4311333326 \\
\hline BE & Belgium & 11094850 & 2399472557 & 2686467242 & 4965753382 & 5688975760 \\
\hline BG & Bulgaria & 7327224 & 1584651699 & 1774187776 & 3279466361 & 3757094483 \\
\hline HR & Croatia & 4275984 & 924762954 & 1035371451 & 1913814248 & 2192546030 \\
\hline $\mathrm{CY}$ & Cyprus & 862011 & 186426291 & 208724256 & 385812700 & 442003243 \\
\hline$C Z$ & Czech Republic & 10505445 & 2272002503 & 2543750826 & 4701951720 & 5386753489 \\
\hline DK & Denmark & 5580516 & 1206892837 & 1351246157 & 2497687323 & 2861455563 \\
\hline $\mathrm{EE}$ & Estonia & 1325217 & 286603408 & 320883298 & 593131119 & 679515937 \\
\hline $\mathrm{FI}$ & Finland & 5401267 & 1168126828 & 1307843446 & 2417460342 & 2769544161 \\
\hline FR & France & 65287861 & 14119743012 & 15808568827 & 29221072530 & 33476888704 \\
\hline $\mathrm{DE}$ & Germany & 80327900 & 17372437805 & 19450310003 & 35952585307 & 41188792633 \\
\hline EL & Greece & 11123034 & 2405567883 & 2693291614 & 4978367774 & 5703427338 \\
\hline HU & Hungary & 9931925 & 2147967883 & 2404880747 & 4445259752 & 5092676384 \\
\hline IE & Ireland & 4582707 & 991097643 & 1109640260 & 2051095128 & 2349820776 \\
\hline IT & Italy & 59394207 & 12845128120 & 14381500556 & 26583233147 & 30454869052 \\
\hline LV & Latvia & 2044813 & 442229744 & 495123696 & 915202736 & 1048494715 \\
\hline LT & Lithuania & 3003641 & 649594555 & 727290874 & 1344348094 & 1540141673 \\
\hline LU & Luxembourg & 524853 & 113509454 & 127086026 & 234909941 & 269122701 \\
\hline MT & Malta & 417546 & 90302273 & 101103093 & 186882244 & 214100152 \\
\hline NL & Netherlands & 16730348 & 3618256298 & 4051026543 & 7488049154 & 8578623796 \\
\hline PL & Poland & 38538447 & 8334672930 & 9331561527 & 17248761680 & 19760906259 \\
\hline PT & Portugal & 10542398 & 2279994293 & 2552698493 & 4718490878 & 5405701445 \\
\hline RO & Romania & 20095996 & 4346141759 & 4865972495 & 8994421745 & 10304387541 \\
\hline SK & Slovakia & 5404322 & 1168787530 & 1308583173 & 2418827677 & 2771110637 \\
\hline SI & Slovenia & 2055496 & 444540146 & 497710439 & 919984156 & 1053972511 \\
\hline ES & Spain & 46818219 & 10125331270 & 11336395864 & 20954562643 & 24006427578 \\
\hline SE & Sweden & 9482855 & 2050847946 & 2296144546 & 4244268222 & 4862412041 \\
\hline \multirow[t]{2}{*}{ UK } & United Kingdom & 63495303 & 13732068214 & 15374525253 & 28418772278 & 32557739819 \\
\hline & EU-28 & & 109125574091 & 122177800785 & 225837418768 & 258728837747 \\
\hline
\end{tabular}

1 Population estimates 2012 (Source Eurostat (2014), op cit [footnote 2]). Population adjustment multipliers: AT 0.1324211493250139, BE 0.1747349721285683;BG 0.1153978901399998;HR 0.0673433119926997;CY 0.0135759805729252; CZ 0.1654523170005189;DK0.0878886427236988; EE 0.0208711028593721; FI 0.0850656150109245; FR 1.028231348073101; DE 1.265099876757813; EL 0.1751788474810491; HU 0.1564198378579279; IE 0.0721739527725382 ; IT 0.9354110334743973; LV 0.0322041616212147; LT 0.0473049321459258; LU 0.0082660129994182; MT 0.0065760139769709; NL 0.2634895371709621; PL 0.6069495723171838; PT 0.166034297056587; RO 0.3164957886727464; SK 0.0851137288060504; SI 0.0323724102867892; ES 0.737349328028248; SE 0.1493473462123647; UK 1.

Source: Special Eurobarometer 449: Gender-based violence 2016

According to the World Health Organisation (WHO) ${ }^{11}$, violence has huge human and economic costs, including the direct costs of health, legal, policing and other services. In the study of European Parliament, The Issue of Violence Against Women in the European Union, it is stated that

"The broader social costs are profound but difficult to quantify. Violence against women is likely to constrain poverty reduction efforts by reducing women's participation in productive employment. Violence also undermines efforts to improve women's access to education, with violence and the fear of violence contributing to (lower) school enrolment for girls. Domestic

${ }^{11}$ See Garcia-Moreno \& Watts (2011). 
violence has also been shown to affect the welfare and education of children in the family",

but also

"social security (benefit payments/rent rebate). Direct costs are: health including medical visits, hospital care and medication; shelters, crisis services, social work, therapy; police, trials, prison. Indirect costs are: deaths, the loss of productivity caused by illness and premature mortality due to violence: production losses due to deaths, work stoppages, absenteeism and incarceration, and finally, the cost of rape and serious injuries"13.

\section{Findings/Results}

\section{The Convention: The European and International Context}

The Convention on preventing and combating violence against women and domestic violence - that is open to non-European countries and to the European Union - is very important because it represents a milestone and the first legally binding instrument creating a comprehensive legal framework not only to protect women against all forms of violence, but also to prevent, prosecute and eliminate violence against women and domestic violence.

Prevention is one of the four core pillars of the comprehensive approach to violence against women and so measures of prevention are strategic in a global vision for the development of a culture of respect and to ensure far-reaching changes in behaviour.

In the draft of the Resolution of the Parliamentary Assembly which was adopted unanimously by the Committee on 29 September 2015, Committee on Equality and Non-Discrimination Promoting best practices in tackling violence against women $^{14}$, we read:

"5. In the light of these considerations, the Assembly calls on Council of Europe member States:

5.1 to sign and/or ratify, if they have not yet done so, the Council of Europe Convention on preventing and combating violence against women and domestic violence (CETS No. 210);

5.2 to implement the provisions of the Convention effectively, in light of the future findings of the Group of Experts on Action against Violence against Women and Domestic Violence (GREVIO) and any recommendations made by the Committee of the Parties;

\footnotetext{
${ }^{12}$ European Parlament, Directorate general for internal policies (2016) at p. 12.

${ }^{13}$ EIGE (2014) at p. 21.

${ }^{14}$ Parliamentary Assembly (2015) at p. 2.
} 
5.3 to draw on the experiences already gathered by other states to develop laws and strategies to effectively fight all forms of violence against women; 5.4 to call upon the expertise of women's support organisations working in the field and national human rights institutions while examining ratifications or the implementation of the Convention in national parliaments;

5.5 to undertake research and data collection in several fields pertaining to the fight against violence against women, including reporting by professionals, compensation procedures and delivery of residence permits; 5.6 to continue to ensure adequate funding for prevention measures and assistance and protection services for victims of all forms of violence against women, including domestic violence".

The Convention is a fundamental international treaty that can be defined as a legally binding instrument creating a comprehensive legal framework in one document but also underlines the attention of European and also International institutions towards this phenomenon, which as a form of human rights abuse, remains a very important issue.

We remember that in 1992 the General Recommendation of the United Nations (UN) Committee on the Elimination of Discrimination against Women (CEDAW Committee) at Articles 6 and 1 contained a definition of genderbased violence: it is «violence that is directed against a woman because she is a woman or that affects women disproportionately» (Article 6) and so it "is a form of discrimination that seriously inhibits women's ability to enjoy rights and freedoms on a basis of equality with men" (Article 1).

In the Declaration on the Elimination of Violence against Women of $1993^{15}$ we read in Article 1

'the term 'violence against women' means any act of gender-based violence that results in, or is likely to result in, physical, sexual or psychological harm or suffering to women, including threats of such acts, coercion or arbitrary deprivation of liberty, whether occurring in public or in private life"

and in Article 2 we read

"Violence against women shall be understood to encompass, but not be limited to, the following: (a) Physical, sexual and psychological violence occurring in the family, including battering, sexual abuse of female children in the household, dowry-related violence, marital rape, female genital mutilation and other traditional practices harmful to women, non-spousal violence and violence related to exploitation; (b) Physical, sexual and psychological violence occurring within the general community, including rape, sexual abuse, sexual harassment and intimidation at work, in educational institutions and elsewhere, trafficking in women and forced prostitution; (c) Physical, sexual and psychological violence perpetrated or condoned by the

${ }^{15}$ United Nations, General Assembly, A/RES/48/104, 48/104, Declaration on the Elimination of Violence against Women, at this link http://www.un.org/documents/ga/res/48/a48r104.htm 
State, wherever it occurs".

Also in the Fourth World Conference on Women in Beijing organised by the UN Commission on the Status of Women, on 4-15 September 1995, the attention given to the phenomenon was considerable and, in fact, in the Declaration and Platform for Action, adopted at the 16th plenary session, 15 September 1995, Article 113 defines violence in a variety of settings:

“(a) physical, sexual and psychological violence occurring in the family, including battery, sexual abuse of female children in the household, dowry-related violence, marital rape, female genital mutilation and other traditional practices harmful to women, non-spousal violence and violence related to exploitation; (b) physical, sexual and psychological violence occurring within the general community, including rape, sexual abuse, sexual harassment and intimidation at work, in educational institutions and elsewhere, trafficking in women and forced prostitution; (c) physical, sexual and psychological violence perpetrated or condoned by the State, wherever it occurs» the definition is similar to Article 2 of Declaration on the Elimination of Violence against Women of 1993".

There are also other European acts and declarations which combat various aspects of gender-based violence as the Directive 2012/29/EU of the European Parliament and of the Council of 25 October 2012 establishing minimum standards on the rights, support and protection of victims of crime, and replacing Council Framework Decision 2001/220/JHA ${ }^{16}$ - which supports the protection of women and development measures ${ }^{17}$ - and Directive 2011/99/EU of the European Parliament and of the Council of 13 December2011on the European protection order $^{18}$ in which European institutions indicate to EU-28 Member States the development of civil law initiatives that work effectively across measures to violence against women.

A previous act was the Resolution of 5 April 2011 in which the European Parliament proposed a strategy to combat violence against women, domestic violence and female genital mutilation as a basis for future legislation of the Member States and defined priorities and the outline for a new EU policy framework to fight violence against women. In this sense the European Parliament included also a framework to fight violence against women (policy, prevention, protection, prosecution, provision and partnership) to be followed up by a Union Action Plan.

\footnotetext{
${ }^{16}$ The EU Directive 2012/29/EU can be consult at this link http://eur-lex.europa.eu/legal-conte nt/EN/TXT/HTML/?uri=CELEX:32012L0029\&from=EN

${ }^{17}$ Point 5 of the EU Directive 2012/29/EU establishes "The resolution of the European Parliament of 26 November 2009 on the elimination of violence against women_called on the Member States to improve their national laws and policies to combat all forms of violence against women and to act in order to tackle the causes of violence against women, not least by employing preventive measures, and called on the Union to guarantee the right to assistance and support for all victims of violence".

18 The Directive 2011/99/EU On the European protection order.
} 
ILO also promoted important messages opposing violence against women, including from the 2009 ILC Conclusions ${ }^{19}$, and development of studies and research at an international level to share knowledge of good practices on eliminating gender-based violence in the general context to promote violencefree working environments.

Figure 3. ILO Policy Framework on Gender-based Violence

\section{ILO policy framework on gender-based violence}

The ILO policy framework on gender-based violence is guided by the 1998 Declaration on Fundamental Rights and Principles at Work, as well as the 2008 Declaration on Social Justice for a Fair Globalization. The latter states that gender equality and non-discrimination must be cross-cutting issues in the four strategic objectives of fundamental principles and rights at work, employment, social protection, and social dialogue and tripartism.

International labour standards are laid out in Conventions that are legallybinding once ratified by member States. The main relevant ones, which include the key gender equality Conventions, are the following:

Forced Labour Convention, 1930 (No. 29)

Migration for Employment (Revised) Convention, 1949 (No. 97)

Equal Remuneration Convention, 1951 (No. 100)

Discrimination (Employment and Occupation) Convention, 1958 (No. 111)

Migrant Workers (Supplementary Provisions) Convention, 1975 (No. 143)

Workers with Family Responsibilities Convention, 1981 (No. 156) Indigenous and Tribal Peoples Convention, 1989 (No. 169)

Worst Forms of Child Labour Convention, 1999 (No. 182)

Maternity Protection Convention, 2000 (No. 183)

Measures called for in ILO Recommendation 200 concerning HIV and AIDS and the world of work include taking action to prevent and stop violence and harassment in the workplace. And a possible instrument on domestic workers' rights was discussed in 2010 by the International Labour Conference, which will conduct its second and final discussion in 2011. The background report providing the basis for this discussion contains reference to member States' obligations to protect domestic workers against abuse, harassment and violence.

Source: ILO Working Paper 3/2011, Gender-based violence in the world of work: Overview and selected annotated bibliography.

${ }^{19}$ ILC (2009) at pp. $13 / 65$ to $13 / 78$. 


\section{Discussion}

The Convention on Preventing and Combating Violence against Women and Domestic Violence: Purposes and Scope

The aim of the Convention in the Articles 1 and 2 is dedicated to the purposes and scope of the international act. This act analyses the prevention of violence, in order to achieve full gender equality to eliminate discrimination against women, existing stereotypes and traditional practices regarding their health.

In order to define the term gender $^{20}$ the Convention refers to roles, behaviour, activities, and socially constructed attributes that a certain society considers appropriate for men and women.

The preamble states "Recognising, with grave concern, that women and girls are often exposed to serious forms of violence such as domestic violence, sexual harassment, rape, forced marriage, crimes committed in the name of socalled 'honour' and genital mutilation, which constitute a serious violation of the human rights of women and girls and a major obstacle to the achievement of equality between men and women".

The preamble also emphasises that violence against women is a manifestation of «historically unequal power relations between women and men», which have led to «dominatio over, and discrimination against, women by men», and that it acknowledges the 'structural' nature of violence which means that it is rooted in society and as such must be eradicated ${ }^{21}$.

Domestic violence ${ }^{22}$ is defined at the Convention to include all acts of physical, sexual, psychological or economic violence that occur inside a family or between family members or between current or former spouses or partners, irrespective of whether or not the initiator of such acts shares the same residence with the victim. The expression "violence against women" based on gender "refers to any direct violence against a woman" affecting them in that they were disproportionately involved.

It is important to recognise that the term women include girls under the age of 18. There is, therefore a precise goal aimed at ensuring the promotion and protection of the rights of each human being to live free from violence in the context of public and private life.

In an international context the member states concluded that it was necessary to ensure that levels of support and protection were standardised across Europe and therefore the Council of Europe organised a task force therefore recommending that a Convention to combat violence against women be developed.

The final activity report of the Council of Europe Task Force concluded that,

\footnotetext{
${ }^{20}$ For a historical profiles and dogmatic framework see Goisis (2014).

${ }^{21}$ See De Vido (2017).

${ }^{22}$ Gracia (2004).
} 
"States have an obligation to exercise due diligence to prevent, investigate and punish acts of violence, whether those acts are perpetrated by the state or private persons, and provide protection to victims. In order to be able to fulfil this obligation, member states need to have evidence-based, comprehensive and coordinated policies in place, including adequate resources for effective implementation, monitoring and evaluation".

\section{Article 1 of the Convention: The Purposes}

The purposes of the Convention are stated in Article 1 (the text of the article is in the box below)" to contribute to the elimination of all forms of discrimination against women and promote substantive equality between women and men, including by empowering women".

\section{Article 1-Purposes of the Convention}

1. The purposes of this Convention are to:

a protect women against all forms of violence, and prevent, prosecute and eliminate violence against women and domestic violence;

$\mathrm{b}$ contribute to the elimination of all forms of discrimination against women and promote substantive equality between women and men, including by empowering women;

c design a comprehensive framework, policies and measures for the protection of and assistance to all victims of violence against women and domestic violence;

$\mathrm{d}$ promote international co-operation with a view to eliminating violence against women and domestic violence;

e provide support and assistance to organisations and law enforcement agencies to effectively co-operate in order to adopt an integrated approach to eliminating violence against women and domestic violence.

2 . In order to ensure effective implementation of its provisions by the Parties, this Convention establishes a specific monitoring mechanism.

The adoption of this instrument (the Convention) was welcomed favourably in the international context ${ }^{23}$ for the holistic approach it offers ${ }^{24}$ and which makes it a reference point internationally for the fight against violence against women, according to the words of Vice Executive Director of UN Women John Hendra during an event on the opening day of the CSW's 56th session in $2012^{25}$. It is therefore very important the emphasis put forward by the Convention on two priority areas of intervention: prevention and access to services by women

\footnotetext{
${ }^{23}$ For a comment see McQuigg (2014b). In the article the author seeks to place the Convention in the context of other developments as regards the analysis of domestic violence as a human rights issue.

${ }_{24}$ See http://www.unwomen.org/en/news/stories/2011/5/un-women-executive-director-michel le-bachelet-welcomes-thecouncil-of-europe-convention-on-preventin

25 Read http://www.unwomen.org/en/news/stories/2012/2/un-women-supports-the-council-ofeurope-s-convention-againstdomestic-violence
} 
who have suffered violence. In general in Article 1 of the Convention importance is given to creating a global framework and integrated approach to women's protection and international cooperation and support for the authorities and organizations in order to carry out said objective.

For this reason the prevision of Article 1 is also present in Article 7 where the commitment of the Contracting Parties to implement policies involving a multitude of actions conducted by the different actors and agencies is specified. These institutions in fact, together have the ability to offer a complete and integrated response to the phenomenon of gender violence.

Most academic commentators remark that the definitions of the Convention are very important:

"the terminology used in the Convention, domestic violence is repeatedly separated out from violence against women more generally. Examples of this can be seen in both the title of the Convention and in the purposes set out in article 1. It appears that such an approach serves two purposes. Firstly, it emphasises the importance which the Convention accords to combating the specific problem of domestic violence, an objective which is certainly to be applauded given the particular prevalence of this form of violence. Secondly, it is recognised in the Convention that men may also be victims of domestic violence" 26 .

On the issue of domestic violence Mullender and Morley comment "Although we normally think of domestic violence as physical, commonly the physical is but one aspect of a pattern of abuse which also includes sexual, emotional, and material abuses" 27 while as Schneider illustrates "practical experience blurs the distinction between physical abuse and other aspects of a violent relationship" 28 .

Article 1 of the Convention, in the contents, refers to the need to design a comprehensive framework and the need to effectively co-operate in order to adopt an integrated approach and these activities are defined in Articles 10 and 11. In fact parties shall designate or establish one or more official bodies responsible for the co-ordination, implementation, monitoring and evaluation of policies and measures to prevent and combat all forms of violence covered by this Convention. For this reason organising bodies shall co-ordinate the collection of data as referred to in Article 11, analyse and disseminate its results.

\section{Article 2 of the Convention: Scope}

The Convention must be applicable both in peace time and in armed conflicts (when the violence on the women is ruthless): the circumstance in which there has always been violence against women reaches particular gravity and ferocity. It is recognised that gender discrimination is easy to find within the tolerance of

\footnotetext{
${ }^{26}$ McQuigg (2014a).

${ }^{27}$ Mullender \& Morley (1998) at p. 6.

${ }^{28}$ Schneider E. (2000) at p.65.
} 
violence against women. The Convention calls on states to adopt comprehensive rules to ensure the effective application of the principle of gender equality ${ }^{29}$.

\section{Article 2 - Scope of the Convention}

1. This Convention shall apply to all forms of violence against women, including domestic violence, which affects women disproportionately.

2. Parties are encouraged to apply this Convention to all victims of domestic violence. Parties shall pay particular attention to female victims of genderbased violence in implementing the provisions of this Convention.

3. This Convention shall apply in times of peace and in situations of armed conflict.

The Convention is very innovative because it acknowledges that domestic violence is one of the forms of violence against women. In this sense we can observe that domestic violence is not a proper subset of violence against women. In fact, in a lot of cases the victim of domestic violence is not a woman. However the violence against women is predominant and so legally speaking, the Convention does not overlook the fact that women are the majority but not the sole victims of violence within domestic walls.

The States have a specific legal obligations with regard to women (Art. 2, para.1), whereas they are encouraged to apply the Convention to "all victims of domestic violence" (Art. 2, para. 2).

So if paragraph 2 of Article 2 encourages the application of the Convention in all case of domestic violence, even if or when it is committed against children and men, it is, however, the prerogative of the contracting parties to define whether to extend the application of the law even to these categories of victims. In this sense all parties recognised the centrality of the size of the gender that characterises the instrument.

The Convention uses a specific language and so member states are 'encouraged' to apply the Convention to male victims of domestic violence. However, there is no actual obligation on States to do so.

With reference to the scope of the Convention in the report, Legal implications of EU accession to the Istanbul Convention, "The scope of EU action covers that area but, as noted above, harmonisation of legislation is a measure to be used only in limited areas of the Convention while other measures that do not require harmonisation of legislation may be used on a broad basis" ${ }^{\prime 30}$.

\footnotetext{
${ }^{29}$ For a comment see De Vido (2014).

${ }^{30}$ European Commission (2015) at p. 57.
} 


\section{References}

Chan K.L. \& E. Cho (2010). 'A review of cost measures for the economic impact of domestic violence', in Trauma, Violence and Abuse, Vol.11 (3): 129-143.

Day T., McKenna K. \& A. Bowlus (2005). The Economic Costs of Violence Against Women: An Evaluation of the Literature, United Nations.

De Vido. S. (2014). 'States' Due Diligence Obligations to Protect Women from Violence: A European Perspective in Light of the 2010 CoE Istanbul Convention', in Benedek W. et al (eds), European Yearbook on Human Rights, Intersentia.

De Vido, S. (2017), 'The Ratification of the Council of Europe Istanbul Convention by the EU: A Step Forward in the Protection of Women from Violence in the European Legal System', in European Journal of Legal Studies, European University Institute, Florence, Spring 2017, Issue 9 (2).

Degani, P. (2000). 'Diritti umani e violenza contro le donne: recenti sviluppi in materia di tutela internazionale', in I Quaderni del Centro diritti umani $\mathrm{Vol}$ 2: 8-12.

Del Vecchio, A. (2011). 'La tutela dei diritti delle donne nelle convenzioni internazionali', in Atti del Convegno in memoria di Luigi Sico, (a cura di Talitha Vassalli di Dachenhausen), Napoli, 2011, pp. 315-329.

Directive 2011/99/EU On the European protection order, can be reached at http://ec. europa.eu/justice/criminal/files/directive_2011_99_on_epo_en.pdf

Duvvury, N., Callan, A., Carney, P. \& S. Raghavendra (2013), Intimate Partner Violence: Economic Cost and Implications for Growth and Development, World Bank.

EIGE (2013). The Index, Gender Equality Index - Report at http://eige.europa.eu/rdc/ eige-publications/gender-equality-index-report

EIGE (2014). Estimating the costs of gender-based violence in the European Union, http://eige.europa.eu/sites/default/files/documents/MH0414745EN2.pdf

EU Directive 2012/29/EU, Establishing minimum standards on the rights, support and protection of victims of crime, and replacing Council Framework Decision 2001/ 220/JHA

European Commission Roadmap A (possible) EU accession to the CoE Convention on preventing and combating violence against women and domestic violence, October 2015, 2015/JUST/010 and EU Commission, Factsheet Q\&A International Day for the Elimination of Violence against Women (24 November 2015) http://euro pa.eu/rapid/press-release_MEMO-15-6150_en.htm

European Commission (2015). 'European network of legal experts in gender equality and non-discrimination', Legal implications of EU accession to the Istanbul Convention, December 2015.

European Parliament, Directorate general for internal policies (2016), Policy department $\mathrm{C}$ citizens' rights and constitutional affairs. Women Right \& Gender Equality, 'The Issue of Violence against Women in the European Union'.

Gracia, E. (2004). 'Unreported Cases of Domestic Violence against Women: Towards an Epidemiology of Social Silence, Tolerance, and Inhibition' in Journal of Epidemiology \& Community Health, Vol. 58(7): 536.

Garcia-Moreno, C. \& C. Watts (2011).'Violence against women: an urgent public health priority', in Bull. World Health Organisation, Vol. 89(1): 2.

Glenn, S., Melis, S. \& L. Withers (2009). 'Gender (in)equality in the labour market; an overview of global trends and developments', in International Trade Union Confederation, Brussels. 
Goisis, L. (2014). "'Gender violence" in light of the istanbul convention. The italian legislation', in Rivista Internazionale di Scienze Giuridiche e Tradizione Romana, Quaderno n. 12/2014.

ILO (2009). Provisional Record 13, Sixth item on the agenda: Gender equality at the heart of decent work (General discussion), Report of the Committee on Gender Equality, ILO, Geneva.

Laing, L. \& N. Bobic (2002). Economic Costs of Domestic Violence: Literature Review, Australian Domestic and Family Clearing House, Sydney.

McQuigg, R. (2010). 'How Could Human Rights Law Be Used by the Courts to Assist Victims of Domestic Violence? A Comparative Study', in International Journal of Human Rights, Vol. 14:(3) 343-363.

McQuigg, R. (2014a). What potential does the Council of Europe Convention on Violence against women hold as regards Domestic Violence, Paper No.2014 B11, p. 4, Queen's University Belfast, School of Law Research.

McQuigg, R. (2014b). A Contextual Analysis of the Council of Europe's Convention on Preventing and Combating Violence against Women, Queen's University Belfast, School of Law Research, Paper No 2014-09.

Mullender, A. \& R. Morley (1998). 'Context and Content of a New Agenda', in Mullender. A. \& R. Morley (eds), Children Living With Domestic Violence, London, Whiting \& Birch Ltd, p. 2-16.

Parliamentary Assembly (2015). Committee on Equality and Non-Discrimination Promoting best practices in tackling violence against women, Rapporteur: Ms Sahiba Gafarova, Azerbaijan, European Conservatives Group. Report adopted unanimously by the Committee on 29 September 2015.

Patel, D.M. \& R.M. Taylor (2011). Social and Economic Costs of Violence: Workshop Summary/Washington, The National Academic Press.

Schneider, E. (2000). Battered Women \& Feminist Lawmaking, Connecticut: Yale University Press.

Skaperdas, S., Soares, R., Willman, A. \& S.C. Miller (2009). The Costs of Violence, Social Development Department, The World Bank. Washington, DC.

United Nations, General Assembly, A/RES/48/104, 48/104, Declaration on the Elimination of Violence against Women,

Walby, S. (2004). The Cost of Domestic Violence, London, Department of Trade and Industry, Women and Equality Unit.

Walby, S. \& P. Olive (2013). Economic aspects of the added value of measures to combat violence against women, Brussels: Report for European Parliament.

Waters, H., Hyder, A., Rajkotia, Y., Basu, S., Rehwinkel, J.A. \& A. Butchart (2004). The economic dimensions of interpersonal violence, Department of Injuries and Violence Prevention, World Health Organization, Geneva.

Zhang, T., Hoddenbagh, J., McDonald, S. \& K. Scrim (2012). An Estimation of the Economic Impact of Spousal Violence in Canada 2009, Department of Justice, Canada, Ottawa. 
